Jeffrey Karnicky

\title{
Ornithological Biography, Animal Studies, and Starling Subjectivity
}

At the end of his recent study of literary birds in British Romantic and contemporary Native American poetry, Skylark Meets Meadowlark: Reimagining the Bird in British Romantic and Contemporary Native American Literature (2009), Tom Gannon writes:

The tempting (at least implicit) conclusion of many works similar to mine runs as follows: know other animals; know thyself better. The modern environmentalist version of this dictum tells us to save other species and the wilderness - for us, either for our own enjoyment or our own survival. But what an insult to other species that is, and what ultimately anthropocentric gall. (316; emphasis in original)

This notion of birds as either a means of appreciating nature or of understanding the human place in the world is a common thread that runs through the history of much American writing about birds, from Walt Whitman's claim in 1878 that, after listening to some birds sing for half an hour, "I have a positive conviction that some of these birds sing, and others fly and flit about here, for my especial benefit" (113), to Henry David Thoreau's claim in 1854 that he was "neighbor to the birds" (58). But perhaps it is John James Audubon, in both his Birds of North America (113) and his Ornithological Biography (1831), who lays the groundwork for seeing birds as "for us."

Audubon published the first volume of his Ornithological Biography in 1831. The book described the habits of, and Audubon's interactions with, all of the bird species that Audubon painted for his Birds of North America (1827-39). While Audubon was not the first to write about the life history of birds, the Ornithological Biography's combination of natural history, emotion, and biography is unique. Part of the Ornithological Biography is "conscientiously packed with physical facts and measurements, close-up observations about how each bird hunted for food, chose its roosting place, fought, sang, played, courted, nested, and nursed its young" (Forkner xiii). For my purposes, the more interesting parts of the Ornithological Biography are those in which Audubon writes of his impressions of a bird's character and of his interactions with individual birds. Many of the accounts describe birds in terms of human values and emotions. The bald eagle is a "selfish oppressor" and "rank coward" with a "ferocious, overbearing and tyrannical 
temper" (Audubon 160, 163). The purple (common) grackle has "nefarious propensities" and is "full of delight at the sight of the havoc which he has already committed" (36), to cite just a few examples.

Audubon also writes anecdotally of his and others' encounters with individual birds, whether it is the bravery of an injured bird that has just been shot, or the character of birds kept as pets by Audubon or his friends. These stories seem to be direct precursors of what could be called a more recent genre of "bird biography" in which a young, injured, or sick bird (or even an egg found in a nest) is raised in a human home. Margaret Stanger's That Quail, Robert, published in 1966, can arguably be seen as the beginning of the specific type of modern bird biography in which I am interested. Robert tells the story of a couple on Cape Cod who bring an abandoned quail egg into their living room. The egg hatches, and the bird becomes imprinted on the humans. She lives with them for many years and becomes a part of the family. This structure informs nearly all bird biographies. A wild bird - egg, nestling, just fledged, or injured - is brought into a home, named (fairly often given a male name when later the bird is revealed to be female, as is the case here), and becomes a part of the household - not quite as domesticated as a cat or dog, but not wild either. After Robert, one can read of Peepers the Talking Starling (2004), Arnie the Darling Starling (1983), Hummingbird in My House: The Story of Squeak (1991), Rosie: My Rufous Hummingbird (1995), Jayson, the True Story of a 20 Year Old Blue Jay (2004), and Wesley the Owl (2008). All of these books, to a greater or lesser degree, hinge on a dual recognition. Wild birds are brought into a human habitat and become domesticated. Wild birds are rejected by the newly domesticated bird as a humanizing narrative takes shape. At the same time, the human moves toward the bird, seeking, but ultimately failing, to understand the bird's "nature." In short, Gannon's "anthropocentric gall" has been the dominant form of bird biography through the twenty-first century. This mode depends on the type of recognition and individuation that can be characterized as interpellation.

In bird biography, birds become subjects as they enter into a relationship with humans through what Louis Althusser calls interpellation: "a material ritual practice of ideological recognition in everyday life" (173), such as a handshake or a statement like "hello, my friend" (176). Through such "hailings," one "becomes a subject" (176), an individualized body called into an ideological system. Althusser, following Freud, writes briefly of "the specific familial ideological configuration" (176) into which infants are born. Two of the key means by which a newly-born infant is interpellated are naming and sexing. As Althusser writes, "it is certain in advance that it [the infant] will bear its Father's Name, and will therefore have an identity and be irreplaceable" (177).

Humanimalia: a journal of human/animal interface studies

Volume 3, Number 1 (Fall 2011) 
Likewise, the infant will "'become' the sexual subject (boy or girl) which it already is in advance." Both of these hailings are key components of "the rituals of rearing and then education in the family" that transform an individual into a subject. These rituals, so familiar within families that they might seem invisible, are, in fact, the narrative content of most bird biographies. That is, bird biography, as a genre, is all about the interpellation of birds: from an undifferentiated population of birds out there "in the wild," individual birds are called into human familial structures.

This strain of interpellation also runs through recent iterations of animal studies, as exemplified in the work of Jacques Derrida and Donna Haraway, two critics who problematize interpellation by pushing it to its limit on the border between the individual and the population. This line of thought points toward a way of thinking differently about animals, a mode of thought that Gannon also points toward in his discussion of birds. Gannon seeks a way of encountering birds that does not view them simply as the unknowable other to a human self: "Yes, we can know that real crow poking outside in the garbage, shitting irreverently on our SUV. In fact, we need to know that bird, this animal, and know that we, too, are animals, however cursed we are by some tragic, speciesist, center-of-the-cosmos hubris" (316). Gannon provides a number of ways of producing this knowledge, mainly through a "critique of the literary use of birds as types and categories" (313). More specifically, Gannon argues that contemporary Native American poetry can "offer us the best opportunity" for interspecies communication that can "cross the border of species" (301). Perhaps the strongest example of this border crossing in Gannon's study is his reading of Sherman Alexie's "Avian Nights" (2003), a poem Gannon calls "an amazing deconstruction of human and avian difference" (299). The section of the poem that Gannon analyzes focuses on a group of European Starlings living in a family's attic, and later exterminated. The poem concludes by asking a question:

Tell me: What is the difference between

Birds and us, between their pain and our pain?

We build monuments; they rebuild their nests.

They lay other eggs; we conceive again.

Dumb birds, dumb women, dumb starlings, dumb men. (76-80)

Gannon writes, "What is the difference, indeed? ... Both are 'dumb,' finally ... humans and birds are just plain stupid, as earth-dwelling organisms irrationally attached to their own" (301). The main difference between starling and human here could be seen

Jeffrey Karnicky - Ornithological Biography, Animal Studies, and Starling Subjectivity 
as one of embodiment. Earlier in the poem, Alexie writes, "But if God gave them opposable thumbs, /I'm positive they would open the doors /Of our house and come for us as we sleep" (72-3). The starling, of course, does not have opposable thumbs, but it can make its voice heard. Both birds and humans, for Gannon, are "inordinately prone to articulate that attachment in songs of love, in songs of mourning. Birds and humans are both inveterate users of language, finally" (301). Gannon sees the starling speaking back to the human in a kind of dialogue.

I want to make a slightly different argument. The European starling, a bird that confounds easy categorization as either individual or population, provides another way of thinking about birds differently. Starlings, in their multiple ways of being in the world, exemplify Felix Guattari's non-dialectical theory of subjectivity, from his The Three Ecologies (1989). Instead of thinking of the subject in terms of self and other, Guattari writes of "existential refrains" that redefine "the relationship between subjectivity and its exteriority" (27). The subject, in this formation, finds its coherence as it responds to, and at the same time reshapes, its surroundings. Listening to the starling's existential refrain can provide a way of encountering a bird's point of view. Such listening leads away from ornithological biography as a form of writing that serves as a means of interpellation and toward an understanding of bird subjectivity that sees and hears all birds differently. An examination of starling subjectivity can show that starlings have their own way of being in the world. They are also the ultimate companion species to humans, as their population growth parallels human alteration of the environment. Thus, starlings are an important site for thinking about the kinds of ethical relations that exist between human and nonhuman animals. In this ethical relationship starlings have benefited immensely since their affinity for humans has helped them to increase their range and population - starlings have survived and thrived in a human-created world. And, from a human perspective, starlings can provide a non-interpellative way of thinking about and living in this world.

Ornithological Biography. In his essay, "Audubon's Ornithological Biography and the Question of 'Other Minds'" (1997), James W. Armstrong writes that the Biography works as a companion to Audubon's more well known book of bird paintings, Birds of America, in that it provides a means of comprehending the interiority of birds through writing that visual representation cannot achieve alone. He writes, "Audubon's need to portray the inner state of birds pushed him towards narrative, for he had to provide the context in which these interior states might arise and be exteriorized - and thus be recognized by us" (Armstrong 115). It is thus through narrative that Audubon hoped to show readers that birds were "not merely automatons ... but subjects in the fullest sense of the

Humanimalia: a journal of human/animal interface studies

Volume 3, Number 1 (Fall 2011) 
term - beings with consciousness and volition" (112). In other words, Audubon employed narrative to call birds into a human framework in which birds, like humans, would be granted the special form of subjectivity that relies on a communicable interiority. Through his painting and writing, Audubon sought a way for humans to recognize birds as fellow subjects.

One prominent example of how Audubon used narrative to argue for the subjective experience of birds can be found in his discussion of what he calls "one of the most interesting of the birds indigenous to the United States of America," the wild turkey (2). Audubon tells a story of a male turkey "which had been reared from its earliest youth under my care, it having been caught by me when probably not more than two or three days old" (14). This bird "became so tame that it would follow any person who called it, and was the favorite of the little village" (14). While tame, the turkey did not associate with the domestic turkeys at the house. Instead, it would spend the night alone on the roof. As the turkey grew, it would spend "a considerable part of the day" in the woods and "return toward night" to its roost. Eventually the turkey flew away and did not return. When it had been gone for several days, Audubon happened to be hunting near some lakes five miles from his home, when he saw "a fine large gobbler cross the path before me, moving leisurely along" (14). He sends his dog after the bird.

The animal went off with great rapidity, and as it approached the turkey, I saw, with great surprise, that the latter paid little attention. Juno was on the point of seizing it, when she suddenly stopped, and turned her head towards me. I hastened to them, but you may easily conceive my surprise when I saw my own favorite bird, and discovered that it had recognized the dog, and would not fly from it; although the sight of a strange dog would have caused it to run off at once (14).

The turkey recognizes the dog, and unrecorded by Audubon, the dog seemingly recognizes the turkey, as Juno stops and turns to Audubon instead of seizing the bird. Audubon notes that he brought the live turkey home with him. He then tells how it was "accidentally shot, having been taken for a wild bird" the next year by someone who did not immediately recognize the turkey as Audubon's pet, until it was brought to Audubon "on being recognized by the red ribbon which it had around its neck" (14). Reflecting on the turkey's recognition of Juno, he asks: "Pray, reader, by what word will you designate the recognition made by my favorite turkey of a dog which had long been associated with it in the yard and grounds? Was it the result of instinct, or of reason - an unconsciously revived impression or the act of an intelligent mind?" (15).

Jeffrey Karnicky - Ornithological Biography, Animal Studies, and Starling Subjectivity 
Audubon never answers these questions. How to account for this recognition seems less important than the act of recognition itself. The turkey sees Juno; Juno sees the turkey. The turkey does not flee and the dog does not attack. The man does not shoot. All of these acts go against instinct. And it is this moment of recognition that overrules instinct. The three actors - Audubon, Juno, and the turkey - all recognize each other as subjects. The turkey recognizes Juno as a specific subject, a dog not to be feared and fled from. Likewise, Juno recognizes the turkey as not just any member of the undifferentiated population of wild turkeys in the woods, but as a specific known subject. What seems astounding about this encounter is that the dog then seems to communicate this to Audubon, through a turn of the head. As Juno looks at Audubon, the mutual recognition, or hailing, is complete.

One cannot overemphasize the importance of mutual recognition here. Had the "favorite turkey" not been recognized, Audubon, who notes that he was hunting, would have most likely shot the bird, and Juno would have then "seized" it. But this does not happen. Even a casual reader of the Ornithological Biography will note that refraining from shooting a bird is an event of great consequence for Audubon, who continually notes the great pleasure of procuring one more specimen. But why does mere recognition prevent the bird from fleeing and the dog from biting? The dog saw the turkey as somehow different from other game birds. While it is not clear that the turkey is capable of reason, it seems to have learned something during its time as a pet. It knew, unlike other wild turkeys, that certain dogs and humans would not harm it. It learned to recognize individuals of those two species. It saw Audubon and Juno, and in a sense, interpellated them as subjects, even as friends who meant it no harm. The bird affirmed Audubon's existence and Audubon spared the bird's life. Instead of a hunting story, Audubon tells an interpellation story.

This exact form of interpellation story can be traced through contemporary bird biographies. Margaret Stanger's That Quail, Robert is marked with many scenes of recognition and response. Soon after hatching in the kitchen of her caretakers, the fledgling northern bobwhite, "even at the age of about an hour ... had followed the sound of human voices and found the first living creatures it was to encounter - two human beings" (14). ${ }^{1}$ From this moment of imprinting, the bird favors human company and rejects birds. Many moments of interpellation follow. The bird is named, sexed (incorrectly, as is discovered a year later when "he" lays an egg), and banded so that "he was legally registered and perhaps protected for the future" (25). After Robert's banding, Stanger refers to her "new status of ornithological citizenship" (25). The bird is

Humanimalia: a journal of human/animal interface studies

Volume 3, Number 1 (Fall 2011) 
house trained and "developed a feeling of complete security and confidence toward any and all humans" (23). Paired with her security around humans was a fear of birds. Robert either cowers in fear or completely ignores any birds she encounters on the front lawn of her house. Stanger writes that "on several of Robert's outdoor excursions his own quail family, all twelve of them, were often quite near him. There was never the slightest sign of recognition, much less reunion, on either side" (20). Stanger concludes, "Robert had repudiated her own kind in favor of her human environment" (104).

Stanger writes, "we should have realized earlier than we did that far from having a bird in captivity, we were helplessly and hopelessly ensnared and enamored" (16). According to Stanger, who was a retired child psychologist, Robert had "spectacular" developments in vocabulary and personality. She notes the "distinctive chirps" (16) that Robert made in different circumstances. Perhaps most interestingly, she thinks of Robert as an individual, intelligent subject. In discussing Robert's behavior, Stanger asks, "Can there be any question as to her intelligence?" (68). Robert clearly recognized, remembered, and acted differently toward different humans. Some she seemed to think of as friends; some she disliked and avoided. In a sense, then, Robert and the multiple humans she encounters mutually recognize one another - human looks at bird and bird looks at human. The title of the book, That Quail, Robert, sums up her relationship with humans perfectly. "That" marks her as a specific quail, easily recognizable and distinguished from the innumerable wild birds in her vicinity. "Robert" marks her naming, obviously, and also the fact that she is no longer just an anonymous member of a quail population living outside.

Robert and Audubon's "favorite turkey" exemplify the interpellative aspect of bird biography. But it is not only "game birds" like quail and turkeys that are subject to this form of narrative. Hummingbirds, robins, and owls have their own bird biographies. Narratives of domesticated animals, such as ducks and parrots, also abound. Perhaps most interesting, though, are the biographies of a so-called invasive species that is sometimes seen as vermin and sometimes seen as a companion species: the European starling.

The European starling, sturnus vulgaris, is the most common bird in America. An estimated 200,000,000 European Starlings live in North America, all descended from 160 birds released in New York's Central Park in 1890 and 1891. These birds were released by Eugene Schieffelin, a member of the American Acclimatization Society, a group that sought to establish American populations of every bird mentioned in Shakespeare's plays. These introductions failed to produce sustainable populations, except for that of

Jeffrey Karnicky - Ornithological Biography, Animal Studies, and Starling Subjectivity 
the starling. European starlings quickly spread across America, partially due to their ability to adapt to and thrive in human-altered environments, especially cities and farms.

At least partially due to its proximity to humans, the European starling is also the most frequently exterminated bird in America. In 2008, 1,703,697 starlings were "lethally controlled" by U.S. Wildlife Services (USDA, "Animals" 373). Starlings tend to flock in agricultural areas, eating and spoiling cattle feed, spreading disease, and damaging crops. The starling is not protected by the Migratory Bird Act; most licensed wildlife rehabilitators will euthanize any injured starling brought to them. Starlings can also be a threat to other cavity-nesting birds, such as red-headed woodpeckers.

But, even as starlings are seen as little more than vermin in many contexts, their flocking behavior has inspired poets and mathematicians. Starlings are also one of the most commonly domesticated "wild" birds. There are many stories of pet starlings; they are named, cared for, taught, and loved. They are mourned when they die. Mozart had a pet starling; when it died, Mozart held a funeral and wrote a poem for it. He wrote, "my heart / is riven apart. /Oh, reader! Shed a tear, / You also, here" (qtd. in West 107). Today, memorial web pages for deceased pet starlings are common. ${ }^{2}$

And while most wildlife rehabilitators will not care for injured starlings, many humans have adopted starlings and raised them as part of the family. Izumi Kyle tells the story of "Kuro," a starling she rescued when she was 12. "He was just a small, featherless hatchling that had fallen out of a nest at my primary school. Two children were teasing him, so I took him away from them and brought him home in a styrofoam cup" (Kyle). The Kyle family adopts Kuro, so that "Our house was his home and our family lived in his cage!" (Kyle). Kuro learned to mimic familiar sounds, "He could say 'good bird!', 'pretty bird!' 'Kiss!', 'Kuro stay!' and many combinations thereof, as well as whistle many tunes including the William Tell overture and 'Pop Goes the Weasel'"(Kyle). Kuro lived for a record 19 years; on his death, his family "was devastated and felt an incredible loss.... I still think about him often and remember all the wonderful experiences as if it was yesterday. I tear at times thinking about him and have many dreams that he is still with us" (Kyle).

Arnie, the Darling Starling was brought into the house of Margarete Sigl Corbo, and raised as a member of the family. Corbo's book, written with Diane Marie Barras, hits all the interpellative notes of bird biography. Arnie is rescued from the wild when Corbo sees that he has fallen from his nest: "He stared past a conical, tightly shut infant

Humanimalia: a journal of human/animal interface studies

Volume 3, Number 1 (Fall 2011) 
beak, his darkly bright eyes insisting, 'Take me home. Immediately'" (2). After resistance - "He's just a wild bird. He doesn't need a name ... He does not get a name" (14) - he is named. "I'd surrendered to the inevitability of Arnold as an appellation" (21). He is set free and returns numerous times $(47,126-127)$. He is described as a human infant and child throughout the text, until Corbo finally notes, "he was family" (52). Arnie ages, eventually dies, and is mourned.

Gently as a feather floating on a breeze, Arnie slipped from this life on February 11, 1983. He would have been four years old that May. His body rests beneath a lush canopy of daisies in Margarete's yard, but in the hearts and memories of the many people he touched, Arnie's spirit is vibrantly alive and as indestructible as dandelions - and starlings. (231)

I will let these two examples stand for the stories of other named starlings such as Salem, Stormy, Jedda, Murphy, and Rudy. ${ }^{3}$ Clearly, these birds form strong bonds with humans. Humans who see starlings as companion species interpellate the birds into human society in the traditional way. Starlings, like other birds subject to biography, are sexed, named, raised as children, cared for in their old age, and mourned in death.

Ornithological biography, then, achieves its purpose of rendering birds as subjects. Bird biography attempts to find evidence of bird interiority and make this interiority manifest and communicable. Bird biography argues, implicitly and/or directly, for birds as quasi-human subjects. Birds become companions to humans as they enter into human conceptions of the world. This relationship between birds and humans bears comparison to other human-animal pairings, such as the more common relationship of humans and dogs. In The Companion Species Manifesto (2003), Donna Haraway famously writes of how she and her dog become companions to one another.

We are training each other in acts of communication we barely understand. We are, constitutively, companion species. We make each other up, in the flesh. Significantly other to each other, in specific difference, we signify in the flesh a nasty developmental infection called love. This love is an historical aberration and a naturalcultural legacy. (3)

What Haraway writes of her dog is also true for the companion relationship between starlings and humans who live together. That is, "love" seems to be the clearest definition of the basis for Corso's affinity for Arnie, Kyle's for Kuro, and Mozart's for his starling. At the same time, though, many of these relationships are written in a manner

Jeffrey Karnicky - Ornithological Biography, Animal Studies, and Starling Subjectivity 
that Haraway wants to resist. In her discussion of human-dog agility training in When Species Meet (2007), Haraway writes that a dog is "not a furry child" (213). As I hope to have made obvious, bird biographers see their bird subjects precisely as feathered children. Perhaps something is lost in this humanizing of birds. In its many attempts to communicate the interior life of birds, ornithological biography takes its interpellative practice as natural, as something that does not call for any kind of reflection or analysis. But animals might have another way of living in the world. The developing discourse of animal studies can offer a means for thinking differently about human-bird companionship.

Deconstructing Bird Biographies. In The Animal that Therefore I Am (2008), Jacques Derrida deconstructs the oppositional terms, as used throughout the history of philosophy, of human and animal. He shows how man has categorized, named, and made other the concept of "Animal." Derrida examines what this opposition hinges on, and he explores what thinking beyond this opposition might look like.

For Cary Wolfe, Derrida's book "is arguably the single most important event in the brief history of animal studies" (570), precisely because of this deconstruction of the human/animal dialectic. Through Derridean-inflected animal studies, according to Wolfe, "we are returned to a new sense of the materiality and particularity not just of the animal and its multitude of forms but also of that animal called the human" (572). That is, in deconstructing the human/animal binary, both terms can become reconfigured, as the dominant term, "human," is shown to depend on what Derrida calls the "subjection of the animal" (Derrida 25). Derrida asks, "Is being-with-theanimal a fundamental and irreducible structure of being-in-the-world, so much so that the idea of a world without animals could not even function as a methodological fiction?" (79). The short answer to this question is "yes." And, as I will argue, starlings can offer proof that a world without animals cannot be thought. Nonetheless, bird biographies implicitly adopt, and confirm, the humanist modes of "reading, interpretation, and critical thought" (572) that Wolfe describes. More importantly, in order to participate in these "humanist modes," ornithological biography buys into a humanist mode of being, embodied in interpellation and grounded in Derrida's "subjection of the animal."

For the humanist, the animal has no name and no ability to speak of itself, or of others for that matter. According to Derrida, "the animal is a word, it is an appellation that men have instituted, a name they have given themselves the right and the authority to give to the living other" (23). By naming other forms of life "animal," man places 
animals in a separate category. Likewise, philosophy denies animals language: "All the philosophers we will investigate say the same thing; the animal is deprived of language" (32). The animal cannot name itself; it cannot even respond to its naming by man. In short, the animal is seen as incapable of response. Animals become an other to be "subjected to farming and regimentalization at a demographic level unknown in the past ... all of that in the service of a certain being and the putative well-being of man" (25). Philosophy and the production of meat for human consumption are linked by a belief in a man/animal dialectic that remains immovable. Animals are not humans; humans are not animals. This is at the heart of what Derrida calls "this event - that is the unprecedented proportions of this subjection of the animal" (25; emphasis in original).

Derrida coins the word animot (a combination of the French for animal and word), as a marker of how one might take apart the dialectic. "Animal words" might make clear that the concept of the animal is "neither a species nor a gender nor an individual, it is an irreducible multiplicity of mortals" (41). He goes on to write, "we have to envision the existence of 'living creatures,' whose plurality cannot be assembled within the single figure of an animality that is simply opposed to humanity" (47). How can this idea, as he suggests, be "envisioned"?

According to Derrida, "it would not be a matter of 'giving speech back' to animals but perhaps of acceding to a thinking, however fabulous and chimerical it might be, that thinks the absence of the name and of the word otherwise, and as something other than a privation" (48). The absence of human language, then, is not a lack. Forgetting language for the moment, what becomes important is remembering the act of the cat looking. "The animal looks at us, and we are naked before it. Thinking perhaps begins here" (29). Bird biography pauses, as Derrida does, at this moment when the animal looks back with its own point of view. But bird biography obscures this point of view precisely through interpellative acts. In order to be rendered as the subject of a biography, the bird's point of view has to be covered over through humanizing practices such as naming. Naming a bird erases its point of view. Robert, Kuro, and Arnie are cut off from any subjectivity outside of the human households in which they live.

According to Donna Haraway, this pause marks the limit of Derrida's thought. In When Species Meet, Haraway writes, "with his cat, Derrida failed a simple obligation of companion species; he did not become curious about what the cat might actually be doing, feeling, thinking, or perhaps making available to him in looking back at him that morning" (20). From within the realm of philosophy that he deconstructs, Derrida

Jeffrey Karnicky - Ornithological Biography, Animal Studies, and Starling Subjectivity 
cannot find a space for his cat to look back. Haraway writes that Derrida "did not seriously consider an alternative form of engagement either, one that risked knowing something more about cats and how to look back, perhaps even scientifically, biologically, and therefore also philosophically and intimately" (20; emphasis in original). In her reading of The Animal that Therefore I Am, Haraway argues that Derrida cannot imagine what his cat sees because of his focus. "He came right to the edge of respect ... but he was sidetracked by his textual canon of Western philosophy and literature" (20). As Haraway notes, "somehow ... the cat was never heard from again in the long essay dedicated to the crime against animals" (20). In short, Haraway locates the limit of Derrida's thought in the cat's gaze that allows him to begin his inquiry. The shared gaze undermines the structure of Derrida's system - right from the start, as Haraway shows, he stops short of engaging an animal's otherness. Haraway writes that while "Derrida is among the most curious of men" (20), in the face-to-face encounter with his cat he became "incurious" (20).

But just as Derrida's cat marks the limit of his thought, it is a bird, the Steller's jay, that marks a limit of Haraway's interrogation of the always contingent "dividing line" that marks "life-and-death relations between human and nonhuman animals" (296). In a short chapter of When Species Meet called "Becoming Companion Species in Technoculture," Haraway describes her work with a group called "Forgotten Felines" to capture, sterilize, and vaccinate a group of feral cats living in a barn in Sonoma County, California. The cats are then "released" with the understanding that the cats will be fed by humans for the duration of the cats' lives. The local raccoons and Steller's jays continually raided "the cats' food arrangements with aplomb" (279), as the humans took part in an "arms race" (279) to secure the cats' food. But the human-supplied cat food is not the only thing eaten in this multispecies encounter. One cat is found dead "with her front leg torn off, presumably by a raccoon" (279). And the cats, of course, do not stick to their human-supplied diet of cat food. Haraway hopes that the cats "will have a fine life keeping the rodents in check" (278). She also notes that the cats kill and eat some Steller's jays. She writes, “I don't care when I see Steller's jays feathers littering their hunting grounds; those avian populations are not threatened by domestic cats around here" (280). The cats take precedence over the other animals - rodents, raccoons, and birds - living near the barn. Haraway writes, "our loyalty seemed due the cats and not the jays and raccoons, because we had produced the food competition and invited - really engineered - the cats into semidependence on us" (279). How was this engineered semidependece produced? And to what effect?

Humanimalia: a journal of human/animal interface studies

Volume 3, Number 1 (Fall 2011) 
A key step in this engineering is an "incuriosity" similar to the one Haraway found in Derrida's interaction with his cat. She writes, "I do remember the statistics of songbird kills by even well-provisioned pet cats in many places - enough to destabilize populations and add to the threat to already threatened species. I wish I knew the score in my region, but I do not" (280). Based on this missing information about her region, Haraway goes on to ask a series of questions.

Would I kill our feral cats if I learned they were a problem for the local quail or other birds? ... Would I know if our dusky-footed wood rat or deer mice populations were in trouble? Does provisioning feral cats carry obligations to follow through on questions of species diversity and ecological balance in microregions? (280-281)

Haraway is not interested in answering these questions; rather, she uses them to establish the complexity of the "multispecies relationships" at work in this specific setting. She writes, "nothing about the multispecies relationships I am sketching is emotionally, operationally, intellectually, or ethically simple for the people or clearly good or bad for the other critters" (280). For the semi-feral cats, this statement is true it is not abundantly clear whether "Trap-Neuter-Release" (TNR) is good or bad - their lives may be better than those of the wholly feral cats, but it is certainly worse than that of indoor cats. Even the name of this practice is in dispute. While TNR is most common, Forgotten Felines defines its practice as the "TTVAR-M method of feral cat control. Trap, Test, Vaccinate, Alter, Release and Maintain" ("Forgotten Felines"). Haraway, in the questions she asks, shows the complexity of the issue for the people involved. For the rodents and birds involved, however, this situation seems a bit less complex, since they are being killed. Some people have even called for the caretakers of feral cat colonies to be prosecuted under The Migratory Bird Act or the Endangered Species Act (TNR Reality Check).

Haraway's short chapter gestures at this complexity but does not address it. Her curiosity here is not strong. Of course, no writer can follow through on all the paths opened up by his or her work. Nonetheless, I remain stuck on Haraway's remark that "I don't care when I see Steller's jays feathers littering their hunting grounds." The choice to favor the cats over the birds and mice is the kind of choice that Haraway notes has to be made all the time in multispecies encounters. Clearly, not every species can win. But the alliance with the cats seems to violate at least two of three "tempting moves" Haraway calls for avoiding in multispecies encounters:

Jeffrey Karnicky - Ornithological Biography, Animal Studies, and Starling Subjectivity 
One must actively cast oneself with some ways of life and not others without making any of three tempting moves: (1) being self-certain; (2) relegating those who eat differently to a subclass of vermin, the underprivileged, or the unenlightened; and (3) giving up on knowing more, including scientifically, and feeling more, including scientifically, about how to eat well - together. (295)

While she is not self-certain, her analysis does include the rodents as vermin, even as she parenthetically brackets this categorization: "(I will leave unexamined the implicit category of vermin)" (280). More importantly, in not seeking answers to her questions about bird populations, Haraway has given "up on knowing more" (280) about this "microregion." My point here is not to point out a weakness in Haraway's argument. Instead, I want to draw a provisional parallel: Haraway's jays equal Derrida's cat equals Audubon's turkey equals Robert the Quail, Arnie the Starling, and all subjects of bird biography. That is, each of these specific animals marks the limit of a system of thought that seeks to engage the animal. And this limit is marked by interpellation.

In a short "philosophical postscript" on interpellation that Haraway appends to "Becoming Companion Species in Technoculture," she writes, "today, through our ideologically loaded narratives of their lives, animals 'hail' us animal people to account for the regimes in which they and we must live. We 'hail' them into our constructs of nature and culture, with major consequences of life and death, health and illness, longevity and extinction" (When Species Meet 278). I want to think about two reciprocal hailings that take place here: the humans' hailing of the cats and vice versa, and the humans' hailings of the jays and vice versa. This pair of reciprocal hailings highlights one important difference-the cats are interpellated into life and the jays are interpellated into death. What can account for this important difference?

The cats are interpellated in multiple ways; they are familiarized with people, vaccinated, spayed or neutered, fed, and named. Haraway writes that the cats have "been interpellated into the modern biopolitical state" (277) and have therefore "earned names to go with their historical identities and subject status" (277). Readers are introduced to "Spike (black male), Giles (black male), Willow (dark gray tabby female), and Max (light gray tabby female" (277). This naming and sexing, as Haraway notes, functions as a marker of the humans' ability to think of them as individual subjects with specific, historical identities. When Species Meet is rife with named, individual, nonhuman animals - Cayenne Pepper (dog), Bahati (dog), (26), Donna (human), and even more abstractly, "Chicken Little" to stand in for domestic chickens in chapter ten.

Humanimalia: a journal of human/animal interface studies

Volume 3, Number 1 (Fall 2011) 
The jays and rodents are never brought into this naming regime - the jays only have their species marker "Stellers"' and the rodents are barely even described at the species level. They get interpellated into the human system as populations, where the life of one is interchangeable with the life of another, so long as the population is not endangered. Haraway says, "those avian populations are not threatened by domestic cats around here" (280), so "I don't care" if the cats kill them. One Steller's jay is no different from another. Any jay may survive by eating cat food or may itself become cat food. Likewise, the rodents might be "dusky-footed wood rat[s] or deer mice" (280). My provisional conclusion, then, is that naming as a process of individuation opens a path into an ethical multispecies relationship that is much more careful and nuanced than the relationship engendered when the species involved are not named beyond the species level. Cats, dogs, primates, and other individualized subjects become central to multispecies relationships, while birds and rodents (among others) become liminal and therefore much more easily endangered by these relationships. In her discussion of Derrida, Haraway argues that his approach cuts him off from "a mortal and finite knowledge that understands [in Derrida's words] 'the absence of the name as something other than a privation'" (21). For the jays and rodents, Haraway and Forgotten Felines have interpellated them into just this realm of name-absent privation. They have no names, and thus no individuation. They exist only as a species or a population. In this case, Haraway's curiosity does not go beyond cats, specifically named cats. Unnamed populations are at the limit of individuation and subjectivity.

Bird biography, of course, does move past the species level as it grants certain privileges to named birds. As they enter into a family assemblage, bird subjects reach their limit as named and humanized, that is interpellated, beings. In writing the life stories of birds, biographers bring birds into a human ethical framework. Birds become understood only as they are subjected to the human. Named, individualized, interpellated birds are separated out from an undifferentiated population. The only birds that bird biography sees and hears are the ones that are given human qualities. It is only through this biographical subjection that birds are heard. The European starling, though, a bird that speaks both metaphorically and literally, might provide a way of thinking around this limit.

Starling Subjectivity. Humans view starlings in two seemingly incompatible ways: as pests to be exterminated and as companion species to be cared for and learned from. Parts of this contradiction can perhaps be explained by starling behavior: as undifferentiated flocks, starlings become vermin when in proximity to humans; when

Jeffrey Karnicky - Ornithological Biography, Animal Studies, and Starling Subjectivity 
flocks take to the sky, they become inspiring. Individual starlings mimic sounds and follow eye-gaze direction, so they seem to be interacting with humans in a one-to-one manner. From a human perspective, in face-to-face encounters, starlings seem to have two sensory aspects of subjectivity as they respond to sound and sight - they seem to see and hear other starlings, other birds, and humans. Huge flocks of starlings, on the other hand, are faceless, and thus awe-inspiring and/or threatening. Starlings exist as both undifferentiated population and individualized subjects.

In flocks, starlings follow a simple rule that produces complex results. In his essay "Going Parallel" (2000), about "the polarities of self/other within contemporary technoscientifically inflected culture" (56-7), Brian Rotman describes the emergence of complexity from such simple starling behavior as "the fact of their flocking, the emergence of a routine or algorithm with a complex dynamical profile from the simultaneous, identical, and simple activity of individuals" (56). This complex, dynamic system flows from one simple rule: Each starling in a flock does what its six closest neighbors do. In this way, following Rotman, one can say that starling flocks are serial and parallel at the same time. Flocks exist in "two modes," as Rotman writes, "the serial, which consists of doing one thing after another (the whole flock forming itself and moving through time) and the parallel (each starling flying in concert with the others) doing many things at once" (57). A recent study suggests that starling vision is a key element of flocking behavior. That is, starlings do what their six or seven closest neighbors do by watching them. They act in a serial manner that is, in fact, also parallel. They are both individuals, responding visually to their neighbors, and flock, acting as a cohesive unit.

This flocking behavior serves an evolutionary purpose because it helps starling flocks confound predators such as Peregrine Falcons. This adaptive behavior produces a secondary effect from a human perspective: beauty. In his essay, Rotman asks, "do starlings have any inkling of how majestic and beautiful their flocking is? Is there a starling sublime?" (56). He cites Richard Wilbur's poem, "An Event," which describes a starling flock as "Like a drunken fingerprint across the sky!" (qtd. in Rotman 56). Of course, it is these same sublime flocks that are often exterminated. A USDA "Fact Sheet - Controlling Starling Damage at Feedlots" notes the damage starlings can do. They cause harm through "consumption of cattle feed" that "can be a significant economic hardship to producers"; their "[f]ecal contamination of cattle feed and drinking water can create disease hazards for cattle, especially calves and pregnant cows"; "Fecal contamination, nesting materials and bird carcasses on and in structures and farm equipment such as dispenser pumps, grinder/mixers, augers, and vehicle engines, can

Humanimalia: a journal of human/animal interface studies

Volume 3, Number 1 (Fall 2011) 
hamper farm operation, and cause costly property damage." In urban settings, "Problems can range from excessive noise to large quantities of excrement deposited on sidewalks, cars, and buildings.... Starlings have transmitted encephalitis and ornithosis" (Vantassel). It is also worth noting that in their native habitat, starlings are seen as a food source for humans in Europe; in France, starling pate is readily available. In short, depending on the context, starling flocks are majestic, threatening, inspiring, expendable, and edible.

Starlings use vision to stay in flocks; another aspect of their visual ability might help explain their status as companion animals. Starlings can follow human eye gaze, and they seem to understand what it means to be looked at. A recent study gives what the authors call "the first explicit demonstration of a bird responding to a live predator's eye-gaze direction" (Carter et al. 1709). As prey animals, starling flocks require vigilant attention to predator threats. Since eye gaze direction is a common signal of intent for mammalian predators - which simply means that a mammal usually looks at its prey before striking - recognition of being looked at gives starlings a "competitive advantage" (1709) over birds that might not be able to read eye gaze direction.

Starling biographies often write of visual contact between bird and human. As I discuss above, Corbo's first encounter with Arnie is one of eye contact, as Corbo "reads a message in his darkly bright eyes" (2). Likewise, their last encounter is also visionbased. As Arnie is near death, "he gazed up at Margarete with love shining in his eyes, breathed a tired sigh, and rested his head against her chest" (231). While there is no scientific evidence linking an ability to recognize a predator's eye gaze and the ability to make eye contact, Corbo's suggestion that Arnie communicated with her visually is at least plausible.

Starlings are also excellent mimics, to the point that they might seem to engage in conversation and respond vocally to human prompts. In their essay "Mozart's Starling," Meredith West and Andrew King have noted that companion starlings give humans "a sense of shared environment with another species, a sensation hard to forget" so that humans become "beguiled by the chance to glimpse a bird's-eye view of the world" (113). How close can humans come to understanding what the starling's point of view might be?

In striving to get a glimpse of a starling's point of view, I do not want to pursue the question of whether or not a starling has a theory of mind. As Carter et al. point out in their discussion of the eye-gaze experiment,

Jeffrey Karnicky - Ornithological Biography, Animal Studies, and Starling Subjectivity 
while we do not deny the interesting possibility that starlings might have a cognitive appreciation of the knowledge state of their predator through recognizing the predator's visual perspective, this type of explanation may not be necessary. The starlings' responses in these experiments could be explained as a result of innate tendencies and conditional learning during their experience prior to the study. (1713)

A theory of mind is not necessary to understand the effects produced by starling eyegaze recognition. Carter, et al. write that the behavior works regardless of what the mechanism driving it may be:

Whether or not the responses involve some sort of mental attribution or theory of mind, and whether or not they are innate or acquired, the result is that starlings are able to discriminate the very subtle eye-gaze clues of a nearby live predator and adjust their anti-predator responses to fluctuations in predation risk in an adaptively beneficial manner. (1714)

In other words, the result does not explain what is happening in a starling's brain when it responds to the eye-gaze of a predator. And such an explanation is unnecessary. Inferring a theory of mind from this behavior would be nothing more than conjecture. Likewise, ascribing a theory of mind, or even a clear reason, to starling mimicry seems impossible and unnecessary. So what do these starling interactions with their environments tell us about their point of view? In recognizing eye-gaze direction, do starlings know that a predator is looking at them? Do they know that the body attached to those eyes wants to consume them? In mimicking and "talking" to humans, do starlings know that they are engaging in conversation? In flocks, do starlings have a mental awareness of the simple, visually guided rule of proximity that guides their collective behavior? Do they know that they are behaving collectively? Do they know they are flocking to avoid a predator? Do they know that their singular action benefits the individual and the flock? Do they know that their flocks are beautiful?

These questions are impossible for us to answer. But humans can understand something about a starling's point of view. We configure subjectivity as individual or collective, as serial or parallel, as named or unnamed, as pet or food, as person or nuisance, but there is no reason to believe that this configuration is correct; there is no reason whatsoever to believe that birds categorize the world in this way. Recognition is not in and of itself part of a self/other dialectic. Birds recognize others, but not necessarily as others. Tom

Humanimalia: a journal of human/animal interface studies

Volume 3, Number 1 (Fall 2011) 
Gannon writes: "I would contend instead that subject and object, self and nature, are false dualisms: when you can make the imaginative leap that 'you' is also a bird, another species, whether this is only metaphorically or mystically true, in the Western scheme of things, the world will be a better ecological place" (316). I agree with Gannon that "subject and object" do not provide a way for understanding bird subjectivity. But I want to emphasize something different than Gannon's important reminder that birds should not be perceived dualistically.

Birds do not exist in the traditional dialectic interpellative understanding of subjectivity. Humans certainly understand starlings this way, but that is no reason to assume that starlings see and hear things in the same way. In his work on how subject formation occurs, Félix Guattari writes of "different ways of being" that he calls "existential refrains." Rather than seeking a theory of mind, or any evidence of interiority, Guattari bases his understanding of subjectivity in external effects. He writes, "it is less a question of having access to novel cognitive spheres than of apprehending and creating, in pathic modes, mutant existential virtualities" (Chaosmosis 120). Guattari deemphasizes traditional notions of subjectivity that locate the self within an egoshaped mind or body. Instead, he stresses the ways that the bodies and minds interact with and influence the world around them. To apply this understanding to starlings and other birds, one can say that bird/human relations should not be configured around a recognition of an interior consciousness that would be evidence of subjectivity. Rather, interactions can be seen as a matter of "apprehension," of having an effect on. From this perspective, bird biography that interpellates birds as human subjects also serves to obscure what might be unique to bird subjectivity. Named, individualized birds might be thought to have a mind, but such an understanding says more about human perceptions of others than it does about birds. Guattari writes that "different ways of seeing and of making the world, different ways of being and of bringing to light modalities of being" (121) can be found in listening to existential refrains.

In "Mozart's Starling," West and King provide a way of thinking about a bird's point of view from a non-human perspective. They explore "the idea that hand-reared birds perceive their human companions in terms of the social roles that naturally exist among wild birds" (110). That is, a hand-reared, or companion, bird might perceive the human other as bird in an act of orni-pomorphism. In a starling's eyes and ears, a human is a starling. As bird behavior changes over time, interactions with other members of their species alters. West and King note that, "in the case of captive birds, humans become the companions for all seasons, with the nature of the relationship shifting with the changing development and hormonal cycles in a bird's life" (110). That is, birds might

Jeffrey Karnicky - Ornithological Biography, Animal Studies, and Starling Subjectivity 
see human-birds as parents, mates, rivals, flock members, etc. This bird apprehension of humans runs parallel to the human apprehension of birds. To use the language of Deleuze and Guattari, this apprehension could be called a double capture: the becoming-bird of the human and the becoming-human of the bird. Such a becoming is not an imitation or even a similarity. Deleuze and Guattari write that "becoming is involutionary, involution is creative.... To involve is to form a block that runs it own line 'between' the terms in play and beneath assignable relations" (Deleuze and Guattari, 238-9). This formulation of becoming is not grounded in the subject; it is a movement between subjects that reconfigures both. Understood as an involvement or an apprehension, the varying nature of the becoming-bird of the human makes sense as humans are constantly reconfigured by birds. Interactions between humans and birds, then, might create an existential refrain through which the boundaries of self and other, or human and bird, become blurred.

From this perspective, starling mimicry may be more than just mimicry. West and King write that "for many birds, acoustic communication is as much visual as vocal experience" (110). In experiments, birds mimicked less in the company of only tapes. When exposed to living beings in a social environment, mimicry increased. Mimicry might be thought of, then, as a means of social interaction. West and King posit the following hypothesis.

We propose that some birds use acoustic probes to test the contingent properties of their environment, an interpretation largely in keeping with concepts of communication as process of social negotiation and manipulation.... Like bats or dolphins manipulating sounds to estimate distance, some birds may bounce sounds off the animate environment, using behavioral reverberations to gauge the effects of their vocal efforts.... [not] for self-reflection but instead a social sounding board with which to shape functional repertoires. (113)

Mimicry is an affective interaction with the world. It is even a model for being in the world. Starlings manipulate their environment with sound and vision, responding to things near them, be they the six or seven nearest starlings in a flock, or the human companion sharing living space. Starlings have a Guattarian notion of being in the world - forming new alliances, or "mutant existential virtualities," with every vocal or visual apprehension of the world. In A Thousand Plateaus, Deleuze and Guattari write of mimic birds, "imitation may not be the best concept for these phenomena, which vary according to the assemblage into which they enter.... It is less a question of imitating a

Humanimalia: a journal of human/animal interface studies

Volume 3, Number 1 (Fall 2011) 
song than of occupying corresponding frequencies" (331). Mimicry becomes a means of interacting with the world; it becomes more of a call and response than an imitation. The starling emits a sounds and the world responds. Interiority, in the sense of a theory of mind, is not necessary to understand the world this way. What counts are exterior effects - a starling's voice and sight alter the world as he/she perceives it; what is inside their heads is less important than the effects produced in the world. Subjectivity is more of a moving outward than a looking inward. Guattari's non-dialectic configuration of subjectivity is useful here, because it does not seem limited, in the way an interpellative sense of self/other is, to human subjectivity. All living things can be said to have an existential refrain.

In mapping these refrains, Guattari writes in The Three Ecologies, "What we must emphasize here is that the work of locating these existential refrains is not the sole province of literature and the arts - we find this eco-logic equally at work in everyday life, in social life at every level, and whenever the constitution of an existential Territory is in question" (46). If one defines "social life at every level" as broadly as possible, to mean any possible interaction that takes place, the existential refrain of a starling can be seen and heard because it is clear that starlings affect the world through their sight, hearing, and vocalizations. In a sense, it becomes impossible for something not to have an existential refrain. Every thing is alive, in this sense, every thing is affecting the world. Starlings, and all birds, are always apprehending and creating, in pathic modes, ways of being.

A return to quails, and to Audubon, can help make this point. In looking at how Audubon attempts to communicate bird subjectivity, Armstrong looks closely at Audubon's painting of, and writing about, bobwhite quails. He cites Audubon's discussion of his painting of a group of quails under attack from a hawk: "The different attitudes exhibited by the former cannot fail to give you a lively idea of the terror and confusion which prevail on such occasions" (qtd. in Armstrong 113). Armstrong questions whether readers and viewers will trust Audubon's representation of quail interiority, whether readers will believe that quails can indeed feel the terror that Audubon illustrates. Armstrong writes, "we do not necessarily trust him when he says he has got the interiority of his subjects right" (113) because we are "rather inclined to dismiss such claims as examples of anthropomorphism" (113). Armstrong rhetorically asks, "do bobwhites feel terror?" (113). From his perspective, we cannot answer this question because we cannot escape skepticism; we cannot access a quail's mind through Audubon's representations.

Jeffrey Karnicky - Ornithological Biography, Animal Studies, and Starling Subjectivity 
Armstrong's logic seems correct here. He argues that Audubon's painting and writing are evidence only that Audubon is "a thinking subject," who in turn asserts that the quail is too. Armstrong writes, "the presence of other minds - in this case, of the birds' minds or feelings - can only be asserted by the testimony of a thinking subject, as such a testimony is not a 'representation' of nature: it is rather more like a promise, or an affidavit" (114). From this perspective, readers and viewers only have access to quail interiority through Audubon's assertion that the quail does indeed have a mind. From an interpellative perspective, we can only see Audubon's dramatization of quail subjectivity: Audubon says that he saw bobwhite quails responding with terror, and thus becoming subjects, but the only evidence is Audubon's representation of this moment. One can never be fully sure that birds are responding to a human hailing in an understandable manner. What Audubon sees, and paints, as terror, might be a marker of a completely different interior state. But the problem here is not Audubon's failure to create a completely convincing illustration of a bird's mind, which seems impossible. Rather, the problem is one of recognition within a specific way of understanding subjectivity.

As a question of recognition, the equation of expression that would make quail terror understandable in terms of human terror must fail. But rather than seeing Audubon's quail portrait as unconvincing evidence of an interior state of mind made manifest in the body, the painting can be considered as an illustration of affect. There is little doubt that a group of quail, or any prey species, under attack from a predator will react by fleeing. But this flight need not be seen as a reflection of an interior state of mind that would always remain inaccessible. Flight in response to attack does give evidence that something is happening; that the quails in Audubon's painting are responding to the diving hawk is beyond dispute. Audubon portrays what Guattari would call the quail's "capacity to be affected" by other things. Bobwhite quails respond to danger just as Robert the quail responded to his environment, just as Audubon's turkey responded to Juno, just as Arnie the starling responded to Corbo. My point is not that all of these responses are the same - they are, in fact, radically different - but that they are all reconfigurations of subjectivity.

Recognizing affective responses as forms of subjectivity should be a key task of animal studies. In her essay, "Literary Animal Agents" (2009), Susan McHugh sees "animal studies researchers as united by a commitment not so much to common methods or politics as to the broader goal of bringing the intellectual histories and values of species under scrutiny" (488). This configuration of animal studies would interrogate what actually happens in interspecies interactions. Such interactions can be seen as what

Humanimalia: a journal of human/animal interface studies

Volume 3, Number 1 (Fall 2011) 
McHugh calls "markings of potentials for different orders of agency beyond the human subject" (487). Bird/human interactions can be one place where such "different orders" might be found, especially if these interactions are understood outside of a dialectic, interpellative understanding of subjectivity. Birds might be understood not as an other that reflects a human self, but as living beings acting in a world that is not dependent on a human definition of self centered around the "I."

Derrida, in his discussion of Kantian ethics and animals, notes the importance of the "I," as well as its human-centeredness. The "I," according to Derrida, is what humanity denies to the animal. Deprived of this "I," Derrida writes, "the animal will lack any 'I think' as well as understanding and reason, response and responsibility" (94). What is at stake here is where the animal resides in an ethical system - on what side of the life and death line it is likely to end up. Derrida writes that there is no simple way to include the animal within a Kantian (or, more broadly, any philosophical) system. He writes, "it is not just a matter of giving back to the animal ... the I of automonstration. It is also a matter of questioning oneself concerning the axiom that permits one to accord purely and simply to the human or to the rational animal that which one holds the just plain animal to be deprived of" (95; emphasis in original). To encounter animal, or more precisely for my purposes, bird, subjectivity would mean an abandonment of the whole system that relies, at base, on the assumption that humans have an " $\mathrm{I}$ " that all other animals lack. Derrida offers no way to move beyond this "giving back"; he notes the complications involved when he writes, "one could go a long way in multiplying these indices and examples, something I don't have time to do" (95). Derrida's gesture here, though, implies that it is the exclusive ascription of the "I" that cannot hold up to close scrutiny. In short, there is no clear dividing line between the human, rational animal that can say "I" and the just plain animal who lacks both an "I" and rational thought

In a different register, cognitive ethologist Marc Bekoff, who, according to Haraway, has "met the gaze of living, diverse animals and in response undone and redone [himself and his] science" (21), offers a means for understanding animal subjectivity that does not depend on the presence or absence of an "I." In Minding Animals: Awareness, Emotions, and Heart (2002), Bekoff succinctly asks, "should we be more concerned with species and their survival than with individuals and their well-being?" (141). He offers no easy answer. He writes, "once an individual animal has been identified and named, there is an immediate change in the way he or she is perceived" (45). But Bekoff is not talking about a lost objectivity; such a thing does not exist. He continues, "I do not have any problem naming animals, and I know of no evidence that unequivocally shows that naming animals produces less reliable scientific results than

Jeffrey Karnicky - Ornithological Biography, Animal Studies, and Starling Subjectivity 
referring to animals with numbers" (47). Here, Bekoff discusses how naming affects human understanding of animals in the realm of scientific study. His endorsement of "biocentric anthropomorphism" (48) provides access to "other animals' behavior and emotion" (48). At the same time, Bekoff does not think that naming and other forms of anthropomorphic language "force us to discount the animals' point of view" (48). His formulation of what an animal's point of view might be resonates with a noninterpellative understanding of bird subjectivity. He writes that "perhaps some animals simply do not need to know who they are" (97) in the way that humans do. Instead of a dualistic self/other mode of bodily awareness, Bekoff posits another way of thinking about individuation. "While individuals surely need to know that they are not another individual, this does not mean they need to be self-aware. Rather, it is necessary and sufficient only that they have a sense of their own bodies and body awareness.... Knowing who you are is not necessarily 'better' than knowing you are not another individual" (97). Bekoff's decoupling of bodily awareness and self-awareness is key. The ability to be an actor in the world does not depend on a human theory of interiority. One does not need to be an "I" to respond. Bekoff writes that "animals do not have to write autobiographies" (97). It is precisely in this not writing that bird subjectivity is most apparent. In not writing autobiographies, birds offer evidence that they are not, to return to Gannon's formulation, "for us." Leaving behind "anthropocentric gall" might require leaving behind the dialectic, interpellative " $\mathrm{I}$ " that grounds a widespread understanding of human and nonhuman subjectivity in both bird biographies and animal studies.

Humans and Starlings. In her essay, "Naming Names - or What's in it for the Animals?," Lynda Birke asks some important questions, often ignored by practitioners of animal studies, about the relationships between humans and animals. She writes, "Whenever I review papers for journals, or read much of the published literature, or do my own research in human-animal studies, I often find myself thinking - but what's in it for the animals? How could/might they benefit? Do they? Does this research I read about take seriously the animals' points of view - or only the viewpoint of the humans thinking about animals?" (1). Birke's questions draw attention to the actual animals being researched and written about. I want to attempt to answer her questions as they apply to the relationships between humans and starlings. How might starlings benefit from animal studies? What can animal studies learn from starlings?

Birke writes that animal studies has "the potential to contribute to sociocultural change, to enable us to take nonhuman animals more seriously as conscious, sentient beings. In that sense, it could be said to be beneficial for animals in a generalized way, in that it

Humanimalia: a journal of human/animal interface studies

Volume 3, Number 1 (Fall 2011) 
gets a few more humans on their side" (5). Certainly, starlings might benefit in this way. Study has shown that starlings have a mind, that they communicate, that they have an awareness of others. Such knowledge, though, probably will not lead to concrete benefits for starlings. To be blunt, animal studies can do little to benefit starlings. A feedlot damaged by starling excrement will not change its extermination practices based on knowledge that starlings probably have some sort of consciousness. But, as a species, starlings have already greatly benefited from human actions. Their entire North American population exists because of human intervention - from their nineteenthcentury introduction in New York to human alteration of habitat. Starlings thrive in human-altered environments. Farms and feedlots provide them ample food and habitat, as do urban and suburban environments. Starlings inhabit every state in the continental United States. Their estimated US population of 200 million is not too far behind the human population of the same area. In short, starlings are incredibly common. One might say that they are the ultimate companion species, sharing every environment that humans have created in America.

But what of a starling's point of view? I have argued that one cannot know what is happening in a starling's mind. But I also want to emphasize the idea that starling subjectivity does not depend on a human understanding of interiority. Starlings do not live dialectically, and animal studies can learn something from this. Another of Birke's questions proves useful here. As she seeks "to examine the relationships between people and animals and how those are experienced by either partner" (7), Birke asks, "How can we go about examining the processes of enmeshing, of coming together, that create a relationship?" (7). To apply this question to my research, I ask: What does the human-starling relationship of the last two hundred years in America tell us about how humans and starlings inhabit the world as companion species?

In her "Animals, Anomalies, and Inorganic Others" (2009), Rosi Braidotti argues that human-animal relationships are essentially a matter of what she calls "affirmative ethics" (529). Braidotti rejects human-animal relationships that are grounded in metaphor and dialectical thought. For Braidotti, "animals are no longer the signifying system that props up humans' self projections and moral aspirations" (528). The sly fox, the brave eagle, and other animal symbols obscure the actual lived experiences of both humans and animals. Braidotti argues that animals bypass the "dialectics of otherness" (526) that has served to create a human-centered "normativity" (526). If we "relate to animals as animals ourselves" (526), Braidotti writes, a new "bioegalitarianism" (526) might be brought into existence. Starling-human relationships provide one way of understanding this worldview. Braidotti calls for "the recognition of transspecies

Jeffrey Karnicky - Ornithological Biography, Animal Studies, and Starling Subjectivity 
solidarity on the basis of our being in this together - environmentally based, embodied, embedded, and in symbiosis" (530). Humans and starlings are the perfect embodiment of this transspecies relationship. The symbiosis between humans and starlings was not designed by either species; nonetheless, it is so firmly entrenched in America that one can hardly find one species without the other in close proximity. From Braidotti's viewpoint, such proximity creates the necessity of an ethical relationship. "The ethical relation is essentially a matter of affinity: being able to have positive encounters with another entity.... By entering into affirmative ethical relations, becoming animal ... engenders possible futures. They construct possible worlds through a web of sustainable interconnections" (531). Humans and starlings have created a world. Where there are starlings, there are humans. Where there are humans, there are starlings.

Thinking about the vastness of this specific companion species relation can lead to new ways of understanding consciousness itself. Braidotti writes, "consciousness is an unfolding of the self onto the world and an enfolding within the self of the world. What if consciousness were, in fact, just another cognitive mode of relating to one's environment and to others?" (530). From this perspective, human consciousness and starling consciousness are not all that different. Both can be understood as a means of being in the world. That is, starlings interact with and respond to the world just as humans do. Such an understanding of the world does not privilege human interiority; interpellation is not the only way of being a subject in this world. The starling-human world shows just how common and widespread companion species relationships are.

At the end of When Species Meet, Donna Haraway writes, "animals are everywhere full partners in worlding, in becoming with. Human and nonhuman animals are companion species, messmates at table, eating together, whether we know how to eat well or not" (301). Starlings are a literal embodiment of this claim. Companion species encounters constitute the world in mundane, everyday ways. Haraway writes of "the ordinary knots of daily multispecies living in a particular place and time" (300); the humanstarling companion species relationship is a perfect example of just such an embodied, historically specific, and common relationship. The human-starling relationship in twenty-first-century America grew from its textual roots by historical accident starlings are the only species introduced by Eugene Schieffelin that established a thriving population in America - and has become a daily marker of the enmeshed, embodied companion species relationships that exist everywhere. There are starlings in my back yard as I write this. I can hear them and see them if I look out the window. If I go outside, they will probably fly off. They are alive. And they have a point of view.

Humanimalia: a journal of human/animal interface studies

Volume 3, Number 1 (Fall 2011) 


\section{Notes}

1. In the first few chapters of the book, when Robert is assumed to be male, Stanger uses masculine pronouns when referring to Robert. Stanger switches to feminine pronouns after Robert lays an egg. For the sake of clarity, I will use feminine pronouns when discussing Robert.

2. See, for instance, Baby Bird at <http://starlings babybird.homestead.com/ babybird.html $>$ and In Memory of Skywalk at <http://www.angelfire.com/biz3/starnus/ skwalk.html>.

3. Links to information about these pet starlings, and many others, can be found at Starling Talk at $<$ http://www.starlingtalk.com/links.htm $>$.

\section{Works Cited}

Alexie, Sherman. “Avian Nights.” New Letters 69.4 (2003): 21-23.

Althusser, Louis. “On Ideology." 1969. Lenin and Philosophy and Other Essays. Transl. Ben Brewster. London: Monthly Review Press, 1971. 103-126.

Armstrong, James W. "Audubon's Ornithological Biography and the Question of 'Other Minds.'" Animal Acts: Configuring the Human in Western History. Ed. Jennifer Ham and Matthew Senior. New York: Routledge: 1997. 103-126.

Audubon, John James. Ornithological biography, or An account of the habits of the birds of the United States of America: accompanied by descriptions of the objects represented in the work entitled The birds of America, and interspersed with delineations of American scenery and manners. 1831. Pittsburgh: University of Pittsburgh, Digital Research Library. 4 Dec. 2007. Online. 15 Aug. 2010.

.Writings and Drawings. 1831-1839. New York: The Library of America, 1999.

Bekoff, Marc. Minding Animals: Awareness, Emotions, and Heart. New York: Oxford UP, 2002.

Jeffrey Karnicky - Ornithological Biography, Animal Studies, and Starling Subjectivity 
Birke, Lynda. "Naming names-or, what's in it for the animals?" Humanimalia: a journal of human/animal interface studies. 1.1 (Sept. 2009): 1-9. http://www.depauw.edu/ humanimalia/issue01/birke.html

Braidotti, Rosi. "Animals, Anomalies, and Inorganic Others." PMLA: Publications of the Modern Language Association of America. 124.2 (Mar. 2009): 526-532.

Carter, J., Lyons, N. J., H. L. Cole, and A. R. Goldsmith. "Subtle cues of predation risk: starlings respond to a predator's direction of eye-gaze." Proceedings of the Royal Society: Biological Sciences 1644 (2008): 1709-1715

Corbo, Margarete Sigl, and Diane Marie Barras. Arnie the Darling Starling, Boston: Houghton Mifflin, 1983.

Deleuze, Gilles, and Felix Guattari. A Thousand Plateaus: Capitalism and Schizophrenia. Trans. Brian Massumi. Minneapolis: U of Minnesota P, 1987.

Derrida, Jacques. The Animal that Therefore I Am. Ed. Marie-Louise Mallet. Trans. David Wills. New York: Fordham UP, 2008.

Forkner, Ben. "Introduction: Writing the American Woods: The Journals and Essays of John James Audubon." John James Audubon. Selected Journals and Other Writings. New York: Penguin: 1996. i-xlii.

Forgotten Felines of Sonoma County. "Forgotten Felines of Sonoma County." n.d. Online. 19 September 2009.

Gannon, Tom. Skylark Meets Meadowlark: Reimagining the Bird in British Romantic and Contemporary Native American Literature. Lincoln, NB: U Nebraska P, 2009.

Guattari, Félix. The Three Ecologies. 1989. Trans. Ian Pindar and Paul Sutton. New Brunswick, NJ: Athlone P., 2000.

. Chaosmosis: An Ethico-aesthetic Paradigm. Trans. Paul Bains and Julian Pefanis. Bloomington IN: Indiana UP, 1995.

Haraway, Donna. When Species Meet. Minneapolis: U Minnesota P, 2007.

Humanimalia: a journal of human/animal interface studies

Volume 3, Number 1 (Fall 2011) 
. The Companion Species Manifesto. New York: Prickly Paradigm Press, 2003.

Izumi, Kyle. “Kuro.” n.d. Online. 10 Apr. 2010.

McHugh, Susan. "Literary Animal Agents." PMLA: Publications of the Modern Language Association of America. 124.2 (2009): 487-495.

Rotman, Brian. "Going Parallel." Substance: A Review of Theory \& Literary Criticism. 29.1 (2000): 56-79.

TNR Reality Check . “TNR Reality Check: Basic Info.” 2010. Online. 12 Sept. 2010.

Stanger, Margaret A. That Quail, Robert. New York: Lippincott, 1966.

Thoreau, Henry David. Walden, or Life in the Woods. 1854. New York: Dover, 1995.

United States Department of Agriculture. "Fact Sheets - Controlling Starling Damage at Feedlots." 16 Mar. 2010. Online. 15 Aug. 2010.

- "Animals Taken by Component/Method Type and Fate by the Wildlife Services Program - FY 2008." 2009. Online. 373. 10 Sept. 2010.

Vantassel, Stephen M., Scott E. Hygnstrom, Dennis M. Ferraro. “Urban Pest Birds: Controlling Damage." U. of Nebraska, Lincoln Extension. 2010. Online. 10 Sept. 2010.

West, Meredith J., and Andrew P. King. "Mozart's Starling." American Scientist. 78.2 (1990): 105-114.

Whitman, Walt. Specimen Days. 1883. New York: Dover, 1995.

Wolfe, Cary. Human, "All Too Human: 'Animal Studies' and the Humanities." PMLA: Publications of the Modern Language Association of America. 124.2 (2009): 564-575.

Jeffrey Karnicky - Ornithological Biography, Animal Studies, and Starling Subjectivity 